\title{
Public Sector Banks in India : Growth of NPAs and Restructuring Aspects ${ }^{*}$ Parmod K Sharma ${ }^{1}$, Dr. Babli Dhiman ${ }^{2}$ \\ 1Ph.D Scholar, Mittal School of Business, Lovely Professional University, Phagwara, Punjab, India ${ }^{2}$ Professor, Mittal School of Business, Lovely Professional University, Phagwara, Punjab, India
}

\begin{abstract}
Article Info
Volume 8, Issue 4

Page Number : $368-381$
\end{abstract}

\section{Publication Issue}

July-August-2021

\section{Article History}

Accepted : 20 July 2021

Published : 27 July 2021

\section{ABSTRACT}

The recent restructuring of Public Sector Banks (PSBs) has generated immense interest in the economic world and the various stakeholders which include investors, depositors, borrowers, the staff working in these banks and the top management of the merging entities. Whereas the depositors look for safety of their monies, the borrowers of merging entities look for new loan products at cheaper rates and faster delivery. The investors will look for resumption of dividend payouts at higher rates and capital appreciation of their investments and the staff looks for better working conditions. The top management will expect more freedom to operate and manage their respective banks more efficiently to grow and earn higher profits. The merger of strong banks was recommended by the first Narasimham Committee in 1991. It has taken almost 28 long years for the Government of India to act on this very critical suggestion of the committee. It is widely believed that this belated step has been initiated due to huge pile of Non Performing Assets (NPAs) with Public Sector Banks and the resultant need for their frequent recapitalization. It is a moral hazard and bad economics for any government to regularly recapitalise PSBs being the major stake holder and having total administrative control of their boards and the top management. To enable PSBs meet the regulatory capital as per international norms and the provisioning requirements enforced by Reserve Bank of India, use of tax payer's money (collected for economic development of the country) is questionable. However it is made clear by the government that the merger is intended to make PSBs bigger and internationally competitive and to build up their capacity to access capital markets for raising resources. A perspective of growth of NPAs and the resultant impact on the financial deterioration of PSBs over a time horizon can give answers to the need for restructuring of Public Sector Banks as repeat of such actions by the government may again be necessitated in future. The improvement in financial performance parameters of PSBs over next few years will answer if act of restructuring by the Government of India results in internationally strong 'too big to fail banks' .

Keywords : Restructuring, Merger, NPA, PSBs, PCA, Financial Ratios. 


\section{INTRODUCTION}

Banks worldwide perform the task of financial intermediation. One set of customers having surplus money deposits it with the banks and another who are in need of credit for their sundry needs borrows from them. The difference in interest paid on deposits and earned on lending activity represents major income of the banks. This lending income is supplemented by other income earned by banks by way of commission and exchange on remittances, letters of credit, guarantees and sale of third party products.

Banking had very less dispersion in India upto late sixties. It was in the hands of private industrial houses who served only their vested interests. As per RBI archives Credit to industry constituted 64.3 percent of the total advances of the scheduled commercial banks in 1967 whereas it was a meagre 2.2 percent to agriculture. Five major cities in the country Ahmedabad, Delhi, Mumbai, Kolkata and Chennai accounted for around 44 percent of the bank deposits and 60 percent of the outstanding bank credit in 1969. As many as 617 towns out of 2700 in the country were not covered by commercial banks and out of 600000 villages hardly 5000 had banks.

It was realised by the government of India that banks were serving only big industrialists and traders and that small, marginal farmers, small businesses and urban poor did not have access to formal sectors of financing. The society at large did not have the benefit of enjoying basic banking services for parking their surplus money or to borrow in times of need. The farmers depended on money lenders or the grain merchants for their production /investment credit and consumption needs. Getting a loan for house construction, buying a car or getting a loan for consumption needs was unthinkable. This realisation resulted in the nationalisation of 14 private sector banks by the Government of India in 1969. These banks were then used largely to serve the social objective of poverty alleviation and all-round development by opening branches in unbanked areas and lending to the priority sectors like agriculture, small businesses and small scale industry. Having realised that the government objective of economic development was facilitated by takeover of private banks, six more banks were nationalised in 1980.With expansion of the economy and the growing needs of society these banks grew in size with passage of time.

Scheduled commercial banks in India comprise of Public Sector Banks (State Bank of India and Nationalised Banks), Foreign Banks, Regional Rural Banks and Other Scheduled Commercial Banks like Private Sector Banks (old and new generation), Small Finance Banks and Payment Banks.

In the early years of Banking in India the volume of public dealing with banks was small and the Banks knew their customers personally. This made easy for them to mobilise deposits from their customers and to lend to chosen few with whom these banks were comfortable. One of the notable things about this phase of banking was that default on a loan was rare. It was a taboo for society to default on bank loans.

With broadening of economy and growing financial requirements of industries and trade, the borrowers started to fail sometimes in honouring their commitments to their banks. This was abetted by dishonesty and greed creeping up in society. It led to the advent of bad loans or Non-performing loans and the malady grew with the intense competition to have credit growth to deploy funds to earn higher interest income by banks in times to come.

Commercial banks in all countries have been facing the problem of Non- Performing Assets (NPAs). In India too the problem of bad loans has become alarming in recent years. As per RBI policy guidelines a Loan/Advance / Bill becomes NPA when Interest and/or instalment of principal / payment remains overdue for a period of more than 90 days. For agricultural loans period is reckoned in relation to short / long duration crops.

NPAs are generally classified into Gross NPAs and Net NPAs. 
Gross NPA is an advance representing the principal and interest due outstanding up to the date of classification. Net NPA is Gross NPAs minus the provisions held against such NPAs as per Reserve Bank of India guidelines.

According to RBI Guidelines, banks classify their non -performing assets in three categories Sub-standard, Doubtful and Loss assets depending on the ageing and / or the securities held in the account.

Equity capital serves as a loss absorption buffer against the losses arising out of bad loans of a bank. It has to be at levels required to absorb anticipated losses and enable the banks to avoid insolvency. In the past Government of India had to recapitalise public sector banks time and again to enable them to meet international capital requirements called BASLE Norms and also to insulate unsecured creditors (depositors). To avoid frequent recapitalisation needs of PSBs Government had to undertake restructuring of these banks.

In 2018 Government of India initiated the process of consolidation of public sector banks. The following mergers have taken place since 2019:

1.State Bank of India +Merger of Associate Banks

2.Bank of Baroda+ Vijaya Bank+ Dena Bank

3.PNB+OBC + United Bank of India

4.Canara Bank+ Syndicate Bank

5.Union Bank + Andhra Bank+ Corporation Bank

6.Indian Bank + Allahabad Bank

The main objective for consolidation of public sector banks is to have banks with scale for building a $\$ 5$ trillion economy. The secondary objectives are as under:

\section{- Enhanced risk appetite}

- Thrust on Next Gen technology for banking

- Wider offerings with enhanced customisation

- Better ability to raise resources from markets (This is very important that instead of so many banks only a few big tap the capital markets to raise equity to keep up the sentiment of investing community).

\section{Review of Literature}

There are many studies seeking impact of NPAs on bank efficiency. Some researchers found that a high level of NPAs not only affected the bank efficiency and loan growth but also the bank capital. Conversely banks with higher bank capital were inclined to undertake more credit risk which eventually resulted in higher NPAs. Researchers have yet to explore fully the impact of NPAs on Capital Adequacy and major financial ratios of Public Sector Banks necessitating their restructuring. Some of the studies are discussed below:

Reddy(2002) did country wise analysis of China, Thailand, Korea , Japan and India as to the causes of NPAs. The study found out that the causes varied significantly across countries with real estate, crony capitalism, directed credit and lack of prudential norms being the critical factors. He also found out that all countries had weak legal mechanism which prevented early resolution of problem. On the flip side the problem was created due to the belief that the government would have to bail out the banks in crisis. Rajaraman and Vasistha (2002) studied 27 public sector banks to investigate variations within a class that is homogeneous on the ownership dimension. It was observed by them that recapitalisation of Indian Bank and United Bank of India (identified as weak banks by Verma Committee ) with operational restructuring may not be a solution since there was a residual problem even after controlling for operating efficiency. Jayakkodi and Rengarajan (2016) by finding a correlation between GNPA and ROA of Public Sector banks concluded that there is an adverse effect of GNPA on ROA. Singh (2016) studied NPAs in scheduled commercial banks during the period 2000-2014 and observed that they impact profitability of banks as Indian banks are highly dependent on income from interest on funds 
lent. Also the NPA level of our banks is still high as compared to foreign banks. Dhananjaya and Raj (2017) analyzed accumulation of NPAs and the provision coverage ratio (PCR) of different banking groups Viz State Bank Group, Nationalised Banks, Private Sector Banks and the Foreign banks. They observed in particular the deteriorating asset quality of particularly Public Sector Banks. Tandon, et.al, (2017) estimated bank specific macroeconomic determinants of non-performing loans and their impact on the banking profitability. It was concluded that NPA management in public sector banks needs attention as it affects the efficiency and profitability exponentially. Rashmi et. al, (2017) examined the relationship between NPAs and financial performance (ROA) of selected public and private sector banks. The banks were selected on the basis of their market capitalization. Sengupta and Vardhan (2017) compared two high bank NPA episodes in post liberalisation India. The paper gives reasons behind these crisis periods, their implications and their resolution. According to these researchers time is of essence in resolution as early recognition and action on resolution mitigates the damaging impact of a crisis.

Kokane and Nerlekar (2017) attempted to confirm whether the measure of recapitalization of PS Banks will reduce the NPA level of these banks and observed that with higher NPA levels the Capital Adequacy Ratio is reducing. The data chosen is from 2009 to 2015 which is before the major recapitalization of public sector banks. Gulati (2018) observed that NPAs had the highest impact on profitability in case of public sector banks whereas the impact was lower in case of foreign banks, new private sector banks and old private sector banks respectively. Nachimuthu and Veni (2019) used various analyses to find out the impact of NPAs on the profitability of the scheduled commercial banks. Garg (2019) observed that due to the presence of a huge set of NPAs it has become difficult for the banks to finance fresh investments to the private sector.
Lots of remedial measures need to be taken to revive lending. One of the most significant is to induce fresh capital via recapitalisation but the same suffers through various challenges like adverse effect on bond yields and on inflation and it is also a moral hazard. V Agarwala and Nidhi (2019) on a critical review of non-performing assets in the Indian banking industry concluded that growth rate in the NPA level shows that the problem is evident not only with small - sized banks but also with big names in the banking space.. The NPAs not only impact the profitability level of these banks but also affects the shareholders' wealth. Devika (2020) The public sector banks have defective lending process, they are not followed by cardinal principles. The recapitalization benefits public sector banks and reduce the stress level of loans. But growing Non-Performing Assets will make capital infused less effective and valuable for small period.

\section{Review of literature on Restructuring of Banks}

There have been good number of research studies internationally as well as in India on Restructuring of Banks. These studies primarily attribute the growing incidence of NPAs for deterioration in financials of all banks. There is therefore the need for prompt action by way of new institutional arrangements to manage impaired assets, different methods of restructuring, evolution of competition after restructuring of banks, the role of macroeconomic policies to make restructuring successful, the clash of corporate cultures affecting the merger process and why mergers happen at all. The expected role of government is also debated in research studies relating to Banking Crises. Some of the research findings are highlighted as under:

Shang (1990) observed that most banks fail because of over gearing of their enterprise borrowers and through their own undercapitalization, mismanagement of asset quality and possibly fraud. The lack of capital depth (including inappropriate bank accounting that disguised the risks and exposure of the asset portfolio) were primary reasons for the 
fragility of the banking system when subjected to macroeconomic shocks or the mistakes of in appropriate government policy. Rhoades (1993) studied efficiency effects of bank mergers and found that acquiring banks on average are more efficient than the target banks. The results indicate that horizontal bank mergers during 1981-1986 did not generally result in efficiency gains. Kunt and Detragiache (1997) investigated the features of the economic environment that tend to breed banking sector fragility and vulnerability and lead to systemic banking crises. Dziobeck and Pazarbasioglu (1997) observed that while bank restructuring programs may be initiated and successfully carried out during a time of economic stagnation, positive growth helps banks to resume lending and return to profitability

Daniel and Saal (1997) suggested that for restructuring to be successful (so that it does not need to be repeated) it requires not only financial restructuring but also operational restructuring of banks. Also it should strengthen management practices, accounting systems and ensuring adequate accountability and disclosure. Systemic bank restructuring is therefore a multiyear process. Abel and Szakadat (1998) after studying the Bank restructuring in Hungary observed that recapitalization of the banking sector was rather costly partly because the occurrence of moral hazards were not prevented. Nevertheless some positive signs can also be seen. The respective portfolios of banks improved significantly and this made the privatization of state owned commercial banks possible.

Milbourn et al., (1999) found that banks need to grow bigger to exploit economies of scale. Moreover competition squeezes margins in traditional commercial banking making it attractive for banks to look for other sources of profitability and these are to be perceived outside commercial banking. Hence the rush to expand scope to offer customers a greater diversity of financial services under one roof.
Hawkins (2000) while commenting on Global financial crisis emphasized that Government must be willing to recognize the scale of the problem and act as soon as possible. It should strongly support supervisors who want to close insolvent banks (as supervisors are likely to be subject to strong criticism from vested interests at such times). Baer and Nazmi (2000) while studying Privatization and Restructuring of Banks in Brazil observed that Public banks were abused for political purposes and although their disappearance will help to clean the financial distortions inherited from inflationary times, the question that will linger about which institution will attend to tasks for which they were originally established i.e. to provide credit for areas, population groups and economic sectors which are not attractive to private banks. Leslie (2000) et.al, while studying financial sector crisis and restructuring of Southeast Asian Nations suggested that Systemic bank restructuring requires strong government leadership because the restructuring seeks to preserve an essential economic infrastructure and entails major macroeconomic and wealth distribution effects. The authors emphasize that experience also indicates that a non-transparent restructuring process may fail to restore the public's confidence in the government and the financial system. Rochet (2003) observed that the eighties and nineties have seen an impressive number of banking crises all over the world with renewed interest of economic research on the causes of fragility of banks and the possible remedies to it. Important reforms were taken during such period in banking supervisory systems. Basel Accord was designed by the Basel Committee on Banking Supervision (BCBS) in 1989. Starting with G-10 BCBS expanded its membership to 28 countries including India (In 2010 BCBS issued a comprehensive reform package called Basel III for more resilient banks \&banking systems).

So it can be assumed that bank restructuring and capitalization started getting serious attention of researchers quite early. Williams and Nguyen (2005) 
support bank privatization and the repeal of state ownership on economic grounds.

Kalaichelvan (2011) in his thesis on Efficacy of Merger and Acquisition in Indian Banking Industry analyzed the pre and post-merger performance of banks which underwent mergers during the post financial sector reform period 1993-94 to 2004-05. It is found that mergers do not result in any notable changes in the liquidity position as well as on its profitability levels. Benzekkoura et.al., (2014) observed that Restructuring benefits as a result of improved performance of the bank by controlling the cost of operations and the introduction of technology for development of products. Siauwiijaya (2017) studied the bank efficiency in Post Merger stage in banking industry in Indonesia. The CAMELS rating of the selected banks suggests private sector merged banks perform better than that of its public counterparts.

Vo and Nguyen (2018) peeped into the link between bank restructuring and bank efficiency and found that privatization of state owned commercial banks, state intervention and mergers and acquisitions do not substantially improve efficiency. Bank efficiency declines during bank restructuring period because of not only transition cost but also the impact of other environment variables such as financial crisis or domestic economy slowdown. Kithinji (2019) studied the effect of bank restructuring on financial performance of commercial banks in Kenya. It is concluded that bank restructuring affects the financial performance through capital restructuring and asset restructuring. Injecting additional capital can increase profitability but increasing asset quality reduces profits of banks.

Deloitte consultancy group (2019) highlight six important factors for merger between banks: Digital capabilities, expanded customer base, geographic growth, culture and management, Risk and regulatory compliances and finally integration of people, processes and technology.
Bersch etal.,(2020) observed that bank distress is usually identified by typical rescue measures taken by supervisors like capital support i.e. capital injections and guarantees as well as distressed mergers (which are often the last resort after previous capital support measures have failed. It was also observed that initial capital support occurs more frequently before a merger than it does in a situation where no merger takes place. Merger makes it substantially more difficult to conduct a control group study, because the bank prior to the merger will be substantially more different from the one afterward with respect to size, regional focus.

\section{Analysis and Interpretation}

The Government of India has undertaken Restructuring of thirteen public sector banks in a non-transparent manner. Researchers have in the past dealt with the issue relating to financial performance of banks through CAMELS Model analysis. However it is not known that if there is any correlation between the financial performance and merger of different PSBs. The question remains to be answered.

The Government of India has decided to restructure thirteen public sector banks by way of a merger. Two more public sector banks have been decided to be privatized. In future more public sector banks need to be restructured by way of mergers, privatization or reduction of stake of the Government of India. Since the process of restructuring has commenced in recent past it will be interesting to watch the outcome by way of success or otherwise of the governments' stated objective for such an act.

\section{3 (a) Historical Perspective}

Liberalization of Indian economy started in 1991. The government appointed various committees to review the banking sector and recommend appropriate policy changes. Narasimham Committee I and II laid the roadmap for reforms in banking sector. These include interest deregulation, reduction of cash reserve ratio, statutory reserve requirements and abolition of 
branch licensing policy, Also risk-based capital requirement standards and uniform accounting practices for income recognition and provisioning requirements for bad debts were introduced. This was in line with Basle I norms suggested by the Basle Committee on Banking Supervision (BCBS). The opening up of banking sector increased competition amongst public sector and private sector banks.

After the Global crisis of 2007-08 which took toll of giant multinationals like Lehman Brothers, Royal Bank of Scotland and Merril Lynch and many more the global economy went in doldrums. Huge shocks were felt in our country also. To revive the Indian economy Government of India embarked upon massive dole out of bank finance for development of various sectors of economy. As private sector banks shyed away from lending the mantle fell upon PS banks due to the influence of big business houses (Crony Capitalism ). Equally important for high growth in credit was the inter-bank competition of Public Sector Banks to show better financial results quarter after quarter.

A new phase of competition between private and public sector banks evolved and their loan books started growing rapidly. Banks besides corporate and priority sector loans also started schemes of Retail Loans like Housing, Vehicle, Education and Personal loans depending upon repayment capacity of borrowers. The loan book of public sector banks alone grew to Rs.18 lakh crore by 2008. This was the time when new sectors of economy were being opened viz. Infrastructure and Industrial sectors like Mining (coal and Iron Ore), Aviation, Roads Airports and Ports construction, Shipping, Oil drilling and Telecom. Since Private Sector banks had a single point agenda to boost their fee based income they wore the mantle of loan syndicators and aggregators. Attractive presentations were made to prospective lenders in posh locations to woo their commitments for taking a share of the proposed financing. Bereft of the technical skills to appraise the industries to be financed, the public sector banks depended solely on the appraisal of Lead institutions like SBI Capital Markets backed by SBI, Axis Bank and the likes of ICICI bank in the absence of term lending institutions like IDBI and ICICI (which took the mantle of universal banking) and IFCI. Between 2008 to 2014 the loan book of PSBs increased from Rs18 Lakh crore to Rs 52 lakh Crore. The reason is that in a zeal to surpass the competitors in credit growth and nonfund based incomes the public sector banks especially went overboard to lend bigger amounts to projects one after another. Some of these were to promoters of unproven track record in the areas of new investments and also to existing promoters without proper due diligence. Many road projects failed because of problems of land acquisition. Also many gas based power projects failed as banks did not ensure gas availability to these projects. All the public sector banks experienced a rise in Gross NPAs (GNPA) in 2015-16. The average GNPA which was 5.20 percent in FY 2014-15 increased to an alarming figure of 9.10 percent in 2015-16.

"The scale of the mess was awe-inspiring. Just 12 accounts had outstanding loans of over 1.72 lakh crore each of them NPA, resulting in bloated balance sheets of banks and corporates without commensurate income. Recklessness in lending and misuse by borrowers was writ large. This was a full blown crisis not understood by the public at large." (Rajiv Kumar 2020). The incidence of NPAs grew and banks were saddled with a non performing loans kitty of around 10.40 lakh crore by March 2018 (11.2 percent of Gross Advances). As per RBI inputs the primary reasons for spurt in stressed assets have been observed to be inter-alia aggressive lending practices, wilful default/loan frauds/ corruption in some cases and economic slowdown. This was a clarion call for government to step in and stem the rot. There was a massive homework to be done at the owner (MOF) and the regulator $(\mathrm{RBI})$. PSBs had massive erosion of capital due to cessation of income on big ticket advances and the resultant provisioning requirement 
on Non-Performing Loans. The government had to announce a recapitalisation package for public sector banks in Oct 2017of INR 2.11 trillion. Another significant step taken by Reserve bank of India in parallel to recapitalization of PSBs was the imposition of Prompt Corrective Action (PCA) on a number of banks whose asset quality, capital and/or profitability did not meet pre-specified thresholds. The objective was to enable banks to conserve capital and regain the financial strength.

To curb the incidence of NPAs in most countries the regulators use solvency regulations initiated by Basle Committee. It envisages a minimum capital level of eight percent of risk weighted assets. The different weights reflect the credit risk of different class of assets. In USA the Savings \& Loans (S\&L) crisis of mid-1980's which forced the government to resolve many thrifts by bailouts led to passage of Federal Deposit Insurance Corporation (FDIC) Improvement Act1991 which in turn gave birth to Prompt Corrective Action (PCA). This was essentially a structured early intervention and resolution approach to avert banking crisis and avert bank insolvency.

\section{3 (b) Measures initiated by the Government to curb NPAs}

All banks in different countries are finding ways to deal with NPAs to remain healthy .The governments too have been taking measures in consultation with their central banks to tackle the problem by legal recourse and institutional framework. Recapitalization of banks too has been done from time to time to maintain the capital adequacy of banks. At a point of time in the past the banks were exhibiting sound financial ratios due to evergreening of loan book (not reflecting true picture of stressed assets and NPAs). Growth of NPAs severely affects the profitability and efficiency of the banks. On the other hand it would also make the credit scarce and costly thereby affecting the economic growth of the country. The growth of NPAs of scheduled commercial banks over the last few years is shown as under:

\begin{tabular}{|c|c|c|c|c|}
\hline \multicolumn{7}{|c|}{ Trend of NPAs of Scheduled Commercial Banks } \\
\hline & Advances & & Non-Performing Assets & (Amount in rupees) \\
\hline Year & Gross & Net & Gross & \\
\hline \multirow{2}{*}{ (End-March) } & & & Amount & As Percentage of \\
\cline { 4 - 5 } & & & & Gross Advances (\%) \\
\hline $2018-19$ & 10287085 & 9709829 & 936474 & 9.1 \\
\hline $2017-18$ & 9266210 & 8745997 & 1039679 & 11.2 \\
\hline $2016-17$ & 8476705 & 8116109 & 791791 & 9.3 \\
\hline $2015-16$ & 8171114 & 7896467 & 611947 & 7.5 \\
\hline $2014-15$ & 7560666 & 7388160 & 323335 & 4.3 \\
\hline $2013-14$ & 6875748 & 6735213 & 264381 & 3.8 \\
\hline $2012-13$ & 5971820 & 5879773 & 194053 & 3.2 \\
\hline $2011-12$ & 4648808 & 5073559 & 142903 & 2.5 \\
\hline $2010-11$ & 3995982 & 4297487 & 97973 & 2.6 \\
\hline $2009-10$ & 3262079 & 3496720 & 84701 & \\
\hline
\end{tabular}

Source : RBI

III. METHODS AND MATERIAL

As shown above, with huge slippage of accounts of scheduled commercial banks to
NPAs the Reserve Bank of India had to step in and put many of the banks (which had high capital erosion due to poor asset quality and poor profitability to support capital accretion) under PCA. Such banks have restrictions on declaring dividends, 
expansion of their risk weighted assets, new lines of business, mobilization of high cost deposits and branch expansion. At one point of time there were twelve banks, eleven in the public sector and one in the private sector, under the Reserve Bank's Revised PCA Framework, with PCA having been imposed on them between February 2014 and January 2018. Presently only three banks are under PCA framework namely Central Bank of India, Indian Overseas Bank and UCO Bank.

The purpose of putting banks under PCA was to enable them to conserve capital. The declining trend of CRARs (capital to risk weighted assets ratio) for PCA banks that started in 2011 due to higher NPAs could be arrested and is now stable due to imposition of PCA on many banks as evident from the following chart :

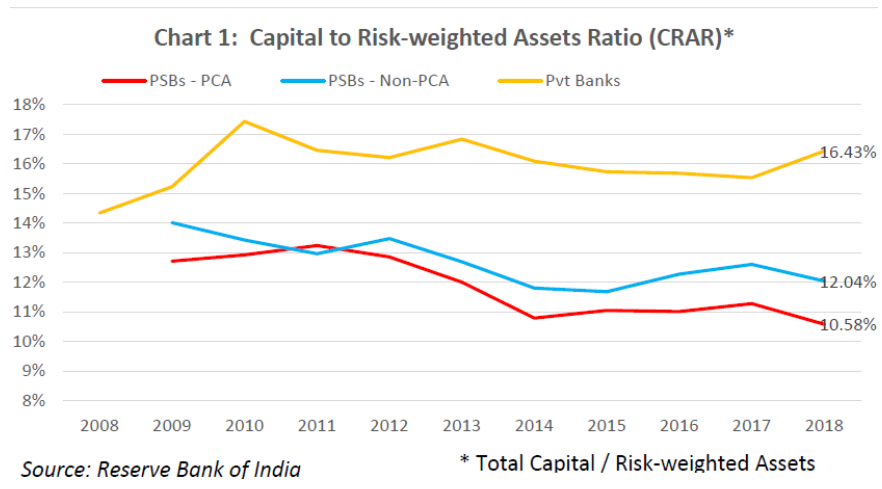

In respect of Asset Quality both the gross and net NPA ratios of PCA banks were almost the same as of non-PCA banks up until about 2014. However after the Asset Quality Review (AQR) by RBI the NPA recognition at PCA banks has led to a sharper rise in gross NPAs relative to non PCA banks and especially to Private banks. It is clear that the asset quality review by RBI made the banks to declare their NPAs which were hidden.

Chart 2 : Gross Non-performing Assets Ratio (GNPA) (\%)*



Chart 3: Yearly Growth in Advances (\%)

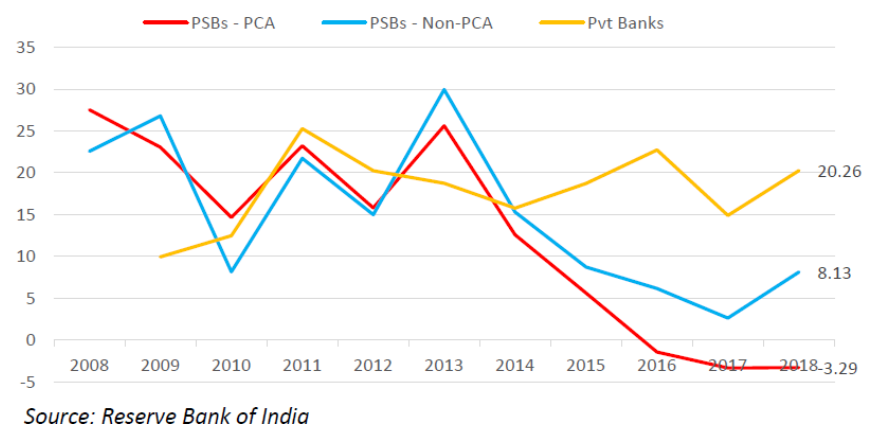

The chart 3 shows how the growth of advances for PCA banks has declined from over 10\%in 2014 to below zero by 2016 and remained contracted since then. Given the evidence presented above on PCA bank's sustained problem of asset quality this was indeed required to save banking industry from collapse.

In the recent past Govt has taken various steps besides Debt Recovery Tribunal and SARFAESI (Securitisation \& Reconstruction of Financial assets \& Enforcement of Security Interest ) to tackle NPAs which include:

\section{> 5:25 Rule-2014}

$>$ Strategic Debt restructuring (SDR)-2015

$>$ Sustainable Structuring of Stressed Assets(S4A)2016

Insolvency and Bankruptcy code Act-2016

The initiative of Govt to have enacted IBC Code in 2016 initially started bearing fruit as the new institutions formed under the code i.e. NCLT and NCLAT were moving to make recovery of bank loans in a time bound manner. But as time has passed the 
recovery through this mechanism for high value Corporate Book NPAs has slowed down due to litigations and also deferment of action under this law due to COVID-19. Simultaneously the government has embarked upon the process of restructuring of Public Sector Banks to make them strong so that they can perform better. Earlier all public sector banks owned by the same owner, Government of India , were competing with one another and trying to be in good books of the owner. Now with proposed merger of Banks the competition will reduce and they can focus on their core competencies, improve balance sheets and go to the market for their capitalisation needs.

\section{3(c) Restructuring of Public Sector Banks}

Restructuring is a word used to effect a fundamental change in an organisation or system. The restructuring or merger of the banks aims to improve the performance of the amalgamated bank to restore solvency and financial performance. It is resorted to take benefit of synergies of merging banks with regard to credit appraisal expertise (to improve lending), branch network consolidation for better service to customers and service differentiation and technological advancement (offering of new digital platforms /products). Capital restructuring of amalgamated entity means efficiency, cost reduction leading to enhanced profitability, rearranging priorities of business keeping in view the changed geographical coverage and expertise of manpower.

In India bank restructuring has so far been attempted using Merger, Change from Private to Government ownership, from Government to Private ownership (as announced by finance minister in Budget 2021 to privatize two public sector banks names of which are to be announced in due course of time.

\section{Impact of NPAs on Financial performance of Public Sector Banks}

The poor appraisal of projects sanctioned with haste resulted in growth of NPAs. The fact that RBI had to introduce schemes like 5:25 scheme and Strategic Debt Restructuring where there is provision for consideration of long gestation periods for infrastructure projects and Sustainable portion of debt which could only be serviced by the cash flows generated from these projects is a testimony to the poor project appraisal by banks. The unscrupulous promoters took benefit of it. The same projects being sold now by the banks through the NCLT mechanism are fetching only 25-35 percent of loan amounts financed earlier by the banks after haircut of 65-75 percent. The NPAs have eroded the capital of almost all Public Sector Banks. With bad debts mounting upto Rs 10.40 lakh crore in March 2018, PSBs account for nearly 85 percent or Rs. 8.84 lakh crore of the country's total NPAs. The largest PSB State Bank of India alone had Rs. 2.23 lakh crore of bad loans. The incidence of NPAs is likely to have impacted almost all financial ratios of these banks which include Capital Adequacy Ratios, CASA deposits, Net Interest Margin, Return On Assets, Return on Equity and Credit Deposit Ratio which are normally harped upon by the managements in investor meets. Government of India has spent roughly Rs 3.5 lakh crore in recapitalizing PSBs in the past few years so that banks can regain their vitality by enhancing qualitative lending while keeping adequate CAGR. The frequent recapitalization needs of PSBs has forced the Government to restructure them with the hope that bigger banks will have economies of scale by technology upgradation expenses, manpower requirements and cutting on loss making branches. Sheer size of new entities may evince interest of investors and may help these with their recapitalization needs. 


\section{Future of Public Sector Bank : Issues and Challenges}

The government has restructured banks with an objective to make them strong after having been hit hard on their financials by mounting non-performing assets. The problem of public sector banks is not over with restructuring. The menace is going to be felt in a bigger way now onwards. The impact of Covid on the economy and the resultant dispensation allowed by way of incremental limits guaranteed by government and restructuring of accounts is likely to generate more than 10 lakh crore of NPAs in the next 2-3 years. Some economists even have gone to the extent of saying that Indian PSBs are sitting over a time bomb. Banks especially PSBs which continue to be directed and controlled to a large extent by Government have many challenges on hand to improve their operations and improve profitability.

On a review of the Bank Mergers in USA it was observed that the bank consolidation hurts consumers (Kress 2020). Also distress at a single large bank poses a significantly greater threat to the economy than distress at several smaller banks with equivalent total assets. The author emphasizes that agencies responsible for merger of banks overlook three statutory factors namely, financial stability, the public interest and financial and managerial considerations.

Restructuring has been implemented for the PSBs by the government in a non transparent manner but the success of the same will depend upon the improvement in macroeconomic factors which have to be initiated by the government by way of relief packages to tackle COVID impact. It is pertinent to note that economy is not growing at a pace where banks can lend bigger money. As such the credit growth of all PSBs is a miniscule single digit growth as on March 2021 that too mainly due to application of interest amount. If economic growth does not pick up the NPAs can not come down. Inflationary trends and boom in real estate prices increases the value of collaterals pledged with the banks. When the economy grows and real estate prices move up, borrowers are able to fetch a higher price for sale of securities charged to the banks to liquidate their NPA accounts. It is therefore imperative that government takes steps to revive real estate/ housing and the industrial sector by better incentives. There is a huge gap to be fulfilled in affordable segment of housing (Mission housing for all ). Government will do well to extend incentives under the scheme beyond 2022.

Also more autonomy has to be acceded to PSBs to operate while having offsite supervision of large credit disbursements. There have been various suggestions by different committees to make a holding company for public sector banks. Though a Bank Board Bureau has been formed it has still not been assigned the desired role of providing assistance to banks to restructure their business strategies and the issues relating to stressed assets. It was mandated to select board members for various PSBs. However it has failed to find suitable candidates for the top positions of Chairman, Managing Director and Executive Directors, in time, for PSBs as many positions still remain vacant. RBI too has to be in an accommodative stance for some more quarters in its monetary policy to help banks have enough liquidity for lending. Banks themselves too have to strengthen their risk management tools and internal control mechanism through technology interventions. Frauds cost banks Rs.1.86 lakh crore in FY 20 of which public sector banks accounted for 80 percent. Therefore while aiming for double digit credit growth and earning profits abundant care is taken to avoid mistakes of past in project appraisals. Fraud prevention is the utmost critical area especially in borrowal accounts. With growing size of the merged entities it becomes imperative to plug loopholes in systems and procedures by making clear job manuals so that Nirav Modi type of frauds can be averted which almost ate away the entire capital of a public sector bank vigorous training is essential so that staff 
of merging banks handling different set of computer software and job procedures can be brought at par. It may be significant to note that Malaysian experience in integrating diverse group of staff and procedures into one new institution have turned out to be much more difficult than initially envisaged (Shang 1991). The reason may be due to the fact that government appointed boards of public sector banks can not be as independent, dynamic and market oriented as their private sector counterparts to tackle various HR and policy issues.

An important objective of restructured entities is to keep existing customers of merged entities in good humour as they bear the trauma of changing faces at counters, locale of branches and new procedures. Keeping an eye on customer satisfaction will thus be a priority for the restructured banks. It is understood that customers are facing immense difficulties in dealing with new entities after restructuring as their branch locations have changed due to optimization of branches. Also the staff with whom the customers had a good rapport have been shifted and suddenly they find new faces on counters. Reserve Bank of India has undertaken a customer survey to know the level of customer satisfaction after merger of public sector banks. The results are likely to surprise the banks on satisfaction levels of customers. The financials of these banks are likely to be impacted in relation to their CASA (Current and Savings) deposits and more so for credit dispensation. With change in corporate culture the credit culture of restructured banks is likely to be impacted. There is a likelihood of shift of accounts to private sector banks whose share of banking business is increasing. RBI data indicates that PSBs market share in loans dipped from 74.3 percent in 2015 to 59.8 percent in 2020 while that of private banks increased from 21.3 percent to 36 percent.

\section{VI.CONCLUSION}

The restructuring of Public Sector Banks has been done by the Government in a non transparent manner. The choice of groupings of different banks could be because of same technology platforms and/ or due to regional considerations. It is understood that corporate cultures and the human factor has not been the consideration for the merger. Besides the thirteen nationalized banks already merged, two more banks are likely to be privatized. The names of Central Bank of India and Indian Overseas Bank (IOB) are being talked about for privatization. Both of these are under PCA framework of RBI. However the final selection may be made on the basis of improvement in financials of these banks. Any divestment by the government in public sector banks must attract investors who look for value in acquisition. Also the government should be able to garner the expected amounts from divestment / sale of shares. Banks to be privatized are perceived to have more toxic assets and such a perception may induce a lower market valuation for these banks. Therefore it may be construed that it is the control of the non-performing assets which ultimately matters for financial health of a bank. Further restructuring of public sector banks will therefore depend on good financials and scope for further improvement.

\section{REFERENCES}

[1]. Agarwala,V.,andAgarwala,N.(2019), A critical review of non-performing assets in the Indian banking industry ,RajagiriMangement Journal Vol 13 No.2,pp13-23.

[2]. Devika.P.(2020) A Study on Recapitalization with reference to Selected Public Sector Banks, International Journal of Advanced Science and Technology, Vol 29, No.4, pp 07-16.

[3]. Dhananjaya,K.andRaj,K. (2017) Assessing the Inter Bank Disparity in Non -Performing Assets (NPAs) Management in Indian Public Sector Banks, International Journal of Financial Management Vol 7 Issue 2 \&3 April \& July.

[4]. Garg, N.(2019), Decoding the Great Indian Recapitalisation Plan: Restoring the Health of 
Public Sector Banks in India, South Asian survey, Vol.26(1), pp.28-54.

[5]. Gulati , P.R.(2018) Comparative Analysis of impact of NPAs on Profitability, International Journal of Research and Analytical Reviews, Vol 5, Issue 2, April - June 2018 pp1763-1770.

[6]. India Today, December 28, 2020 pp22-31.

[7]. Jayakkodi,D. and Rengarajan,P. (2016), Impact of non -performing assets on return on assets of public and private sector banks in India , International Journal of Applied Research, 2(9) pp 696-702.

[8]. Kumar Rajiv(2020) Ex-Secretary , Ministry of Finance, Government of India, The Storm Before the Lull, The Economic Times, 27th Feb 2020.

[9]. Kokane, S. and Nerlekar,S.(2017),Recapitalization of Public Sector Banks-Will it reduce the NonPerforming Asset Levels?,IOSR Journal of Economics and Finance, pp84-91, SIMSR International Finance Corporation(SIFICO2017)

[10].Nachimuthu,K. And Veni, M.(2019), Impact of non -performing assets on the profitability in Indian scheduled commercial banks, African Journal of Business Management, Vol.13(4) ,pp.128-137.

[11].Rajaraman , I., and Vasishtha, G. (2002), Non Performing loans of PSU banks : Some panel results. Economic and Political Weekly, 429435.

[12].Reddy,P.(2002), A comparative Study of Non PerformingAssets in India in the Global contextsimilarities and dissimilarities, remedial measures, The Indian Institute of Management , Ahmedabad, Oct,2002 .

[13].Rashmi Kumari, Singh,P.K.and Sharma,V.C.(2017), Impact of Non -Performing Assets (NPAs) on Financial Performance of Indian Banking Sector, IIS Univ.J.Com. Mgt Vol.6(1),122-133 .

[14].Sengupta ,R.and Vardhan, H. (2017), Nonperforming assets in Indian Banks: This time it is different, Econpapers.repec.org.
https://EconPapers.repec.org/RePEc:ind:igiwpp:2 017-019. Accessed February 14, 2020.

[15].Shaktikanta Das, Governor , Reserve Bank of India, Indian Banking at Crossroads: Some Reflections, First Annual Economics Conference , Amrut Mody School of Management, Ahmedabad University, Nov 16,2019.

[16].Singh ,V.(2016), A study of Non Performing Assets of Commercial Banks and it's recovery in India, Annual Research Journal Of SCMS , Pune Vol 4, March2016.

[17].Tandon,D.,et.al,(2017) Non-performing assets and profitability of Indian banks: an econometric study, Int J. Business Competition and Growth, Vol.6, No1.

[18].References for Review of Literature on Restructuring of Banks:

[19].Acharya, V. (2018), Deputy Governor, RBI, Prompt Corrective Action: An essential element of Financial Stability Framework, Remarks delivered at the Indian Institute of Technology, Bombay Oct 12.

[20].Abel., and Szakadat,L.(1998), Bank Restructuring in Hungary, ActaOeconomics, 49 No.1/2 pp.157-189.

[21].Bersch,J.et.al., (2020), The real effects of Bank distress: Evidence from Bank bailouts in Germany, Journal of Corporate Finance,Vol. 60, Feb.

[22].Benzekkoura,L.,et.al., (2014), Restructuring of Banking: Concept, Justifications, Stages n Results, Mediterranean Journal of Social Sciences, Rome Vol.5,No.4,March.

[23].Baer,W., and Nazmi, N. (2000), Privatization and Restructuring of Banks in Brazil,Thequarterly journal of Economic and Finance Vol 40, pp. 324.

[24].Demirgue-Kunt, A. and Detragiache, E. (1997), The Determinants of Banking Crisis: Evidence from Developing and Developed countries,IMF Working paper,WP/97/106. 
[25].Dziobek, C. and Pazarbasioglu,C. (1997), Lessons from Systemic Bank Restructuring: A Survey of 24 countries.IMF Working Paper WP/97/161.

[26].Deloitte Consulting GroupPaper,(2020),Banking and capital markets M\&A outlook- Partnering to navigate the future.

[27].Daniel,J.and Saal, M. (1997), Macroeconomic Impact and Policy Response,Systemic Bank Restructuring and Macroeconomic Policy edited by William E Alexander et.al.

[28].Indian Finance Minister's Presentation , Measures to achieve higher economic growth , Progress since announcements on 23-08-2019.

[29].Hawkins, J.,(2000), Restructuring Banking Systems, Global Financial Crisis- Lessons fromRecent Events edited by Bisignano R, Joseph et al.,Kluwer Academic Publishers, Boston.

[30].Kalaichelvan, K. (2011), Efficacy of Merger and Acquisition in Indian Banking Industry Ph.DThesis, Dept. of Commerce, Pondicherry University.

[31].Kithinji,A.M.(2019), The effect of Bank Restructuring on financial performance controlled by Customer Deposits: An empirical investigation of commercial banks in Kenya, International Journal for Innovative Research in Multidisciplinary Field, Vol 5(1) Jan.

[32].Kress, J.C. (2020) Modernizing Bank Merger Review, Yale Journal on Regulation,Vol.37, 435.

[33].Milbourn, T.T.et.al., (1999), Megamergers and expanded scope:Theories of bank size and activity diversity , Journal of Banking \& Finance,Vol.23, pp.195-214.

[34].Rhoades, S.(1993) , Efficiency effects of horizontal (in -market) bank mergers, Journal of Banking and Finance, Vol.17,pp.411-422.

[35].Rochet J.C. (2003), Why Are There so Many Banking Crises? CESifo Economics Studies, Vol.49,2/2003, pp.141-155.

[36]. Shang, A. (1991), The Art of Bank Restructuring-Issues and Techniques
,Economicdevelopment Institute of the World Bank,Catalogue No.340/054.

[37].Siauwijaya, R. (2017), The Evaluation of Bank Efficiency in Post Merger Stage in Banking Industry Binus Business Review Vol 8(2), August, pp133-139.

[38].Teo, L et.al;(2000), V Bank Restructuring ;Financial Sector Crisis and Restructuring: Lessonsfrom Asia. IMF Publication.

[39].Vinh Vo, Xian Nguyen, H.H. (2018), Bank restructuring and bank efficiency -The case of Vietnam, Cogent Economics \& Finance, Vol 6: 1520423.

[40].William J. and Nguyen N. (2005), Financial liberalization crisis and restructuring: $A$ comparative study of bank performance and bank governance in South East Asia, Journal of Banking \& finance, Vol 29 pp 2119-21

\section{Cite this article as :}

Parmod K Sharma, Dr. Babli Dhiman, "Public Sector Banks in India : Growth of NPAs and Restructuring Aspects", International Journal of Scientific Research in Science and Technology (IJSRST), Online ISSN : 2395-602X, Print ISSN : 2395-6011, Volume 8 Issue 4, pp. 368-381, July-August 2021. Available at doi : https://doi.org/10.32628/IJSRST218464

Journal URL : https://ijsrst.com/IJSRST218464 